\section{Comparison of government recommendations for healthy eating habits in visual representations of food-based dietary guidelines in Latin America}

\author{
Comparação das recomendações governamentais \\ para hábitos alimentares saudáveis expressos \\ em representações visuais de guias alimentares \\ baseadas em alimentos na América Latina
}

\author{
Comparación de recomendaciones gubernamentales \\ sobre alimentación saludable, expresadas en \\ representaciones visuales de guías alimentarias \\ de Latinoamérica
}

Mayara Sanay da Silva Oliveira 1

Mark Anthony Arceño 2

Priscila de Morais Sato 1

Fernanda Baeza Scagliusi 1

\begin{abstract}
Visual representations of food-based dietary guidelines (FBDG) express diverse dietary and sociocultural norms, especially as they relate to healthy eating habits. This article investigates government recommendations for healthy eating habits expressed in the visual representation of Latin American FBDGs. Drawing on 15 images published between 1991 and 2017, we conducted an anthropological visual analysis guided by the methodology proposed by James Collier and Malcolm Collier: unstructured analyses, open viewing analyses, structured analyses and microanalyses. Here, we explore government recommendations based on visual representation shapes, food classification systems, lifestyle recommendations and embedded sociocultural elements. Our main findings relate to how dietary and sociocultural norms are used to promote eating practices considered healthy. Dietary norms focus on variety, proportionality, and moderation, as expressed in terms of food classification and food standards considered healthy. Sociocultural norms are referenced by the use of cultural symbols as strategies to promote traditional foods, cooking practices, commensality, water consumption and physical activity. Ultimately, we argue that FBDG visual representations contain embedded messages that counsel individuals to plan, buy, prepare and consume food with family; to consume foods considered healthy; to pay full attention to their meals, without distractions, such as television and cell phones; and to celebrate traditional, local and/or native foods and culinary preparations.
\end{abstract}

Healthy Diet; Nutrition Policy; Qualitative Research

\author{
Correspondence \\ M. S. S. Oliveira \\ Praça Claudino Alves 05, apto. 3C, Atibaia, SP \\ 12940-800, Brasil. \\ mayarasanay@gmail.com \\ 1 Universidade de São Paulo, São Paulo, Brasil. \\ 2 Department of Anthropology, The Ohio State University, \\ Columbus, U.S.A.
}




\section{Introduction}

Food-based dietary guidelines (FBDGs) are tools for promoting healthy eating habits and lifestyles for a country's population. FBDGs are government-written and/or -endorsed textbooks and present various formats, including textbooks, brochures, booklets, and posters 1. FBDGs may also be communicated to broader publics by translating population-specific nutritional goals into easily understandable images, referred to here as visual representations here 1,2,3. Importantly, FBDGs aim to contextualize scientific knowledge on food and nutrition within environmental, social, economic, and cultural aspects of human nourishment 1 .

The use of dietary guidelines emerged in the 1970s, understanding food and nutrition as health determinants. These documents emphasized nutrients rather than foods and food choices ${ }^{4}$. The incentive to develop FBDGs began at the first International Conference on Nutrition, which identified FBDGs as actions to improve food consumption and nutritional well-being 2,5. At the conference, several countries adopted the global Plan of Action for Nutrition, which included a section on promoting healthy diets and lifestyles, prompting governments to develop FBDGs to provide country-specific guidance 1,2,3. The Food and Agriculture Organization of the United Nations (FAO) has encouraged Latin American countries to develop their own FBDGs, and the main Latin American health agencies - the Institute of Nutrition of Central America and Panama (INCAP) and the Pan American Health Organization (PAHO) - have assumed responsibility for developing, implementing and evaluating dietary guidelines 6. In 2014, the FAO published a report entitled El Estado de las Guias Alimentarias Basadas en Alimentos en América Latina y el Caribe 2, which presents the elaboration, implementation, evaluation and revision of FBDGs in our region of study. At the time of the publication, 10 Latin American countries presented visual representations of their FDBGs 2.

Researchers have focused on developing, implementing, evaluating and updating Latin American dietary guidelines 6,7,8; however, they did not evaluate the visual strategies used to promote healthy eating and lifestyles. Others have compared Latin American visual representations with images from different continents (Americas, Asia, Africa and Europe) 9,10,11. Among these studies, just one used qualitative methods 7 , and only two analyzed Latin American FDBGs as a whole group (though without considering visual representations) 6,8. Our study addresses this literature gap by qualitatively engaging with FBDG visual representations of Latin America.

Specifically, our primary goal is to investigate government recommendations of healthy eating habits as expressed in Latin American FBDG visual representations. Here, we view visual representations as symbolic vehicles that have power and potential to communicate recommendations concerning eating habits 1,3 . As such, we explore how FBDGs express cultural similarities and differences throughout Latin America regarding culturally-defined foods, ways of preparing and consuming them, and eating patterns considered healthy.

\section{Material and methods}

\section{Selection of materials}

To select images for our qualitative, documentary-based review of Latin American FBDG visual representations, we examined the publication El Estado de las Guías Alimentarias Basadas en Alimentos en América Latina y el Caribe 2 and the FAO's online repository of worldwide FBDGs 12 . We accessed images electronically through the FAO's website (http://www.fao.org/nutrition/nutrition-educa tion/food-dietary-guidelines/en/) or that of the government agency responsible for their dissemination. From March to April 2017, we searched for visual representations that were the latest versions of visual representations launched, directed at people over two years old and publicly available. Representations aimed at health professionals or other service providers were not included. Regarding matters of ethical approval, the Brazilian resolution of ethics in health research 13 exempts from the need to obtain approval from an ethics committee for documentary-based investigation with public documents of unrestricted access. 


\section{Construction of the inventory}

Fourteen Latin American countries have developed FBDG visual representations to accompany government-endorsed and -printed FBDG textbooks (Argentina, Bolivia, Chile, Colombia, Costa Rica, Cuba, Dominican Republic, Guatemala, Honduras, Mexico, Panama, Paraguay, Uruguay, and Venezuela); this does not include Brazil and El Salvador ${ }^{2}$. We were unable to locate Nicaragua's FBDG on its Ministry of Health's website. We also reviewed Venezuela's government-sponsored indigenous representation. We organized the selected visual representations $(n=15)$ in an inventory including country, official name, publication year, update year, development process and stakeholders, and description (Box 1). Most documents permitted the cited reproduction of images, though we avoided including them here. Instead, we inform readers about the methods used to access these materials and emphasize the provided bibliographic references.

\section{Data analysis}

We performed an anthropological visual analysis, an interpretive approach concerned with relating an image to all objects and ideas of the social group that produced it and the researchers that interpret the meaning of those images, objects, and ideas 14 . We engaged in a "direct visual analysis", considering FBDG visual representations as "cultural images" 14 and examining the content and character of our selected images as data 15 . The scope of anthropological visual analysis frames images as human experience that evidence how their producers have re-constructed "reality", as well the relationship between producers and subject in which both play roles in shaping their character and content 15. Methods previously pioneered by visual anthropologists James Collier and Malcolm Collier are guided our analysis. This process entails: (a) unstructured, open viewing analyses; (b) structured analyses; and (c) microanalyses 15,16.

\section{- Unstructured, open viewing analysis}

We surveyed the visual representations individually and collectively to elicit emerging comparative themes. We looked for elements shared among all images, as well as for those that stood out as unique. We extracted and coded these data from the FBDGs, organizing them in a matrix according to shape, food classification system, physical activity recommendations, water consumption recommendations, and perceived sociocultural elements (Box 2).

\section{- Structured analysis}

We compared how the images are similar to or different from one another within each of the abovementioned categories and in response to our overarching themes. We interpreted the duplication or frequency of specific images as indicative of common resources or practices (e.g., consuming particular quantities of an ingredient or a given food group) throughout the region. This aided our interpretations of what each element told us about government recommendations for healthy eating and lifestyles throughout Latin America. In addition, and as an ethical care strategy for preventing misrepresentation or altering meaning ${ }^{17}$, the first author read the FBDG visual representations several times and referenced the accompanying textbooks as needed to support interpretations, highlighting characteristics related to the categories. Throughout this recursive process, the first author raised emergent themes (e.g., commensality, cooking practices, traditional foods) (Box 2), which were discussed with two researchers with experience in cultural food anthropology and nutrition until consensus on the categories was met 17 .

\section{- Microanalysis}

We conducted more detailed analyses of each FBDG visual representation to better understand not only the norms embedded in the respective composite images but also the entire collection of Latin American visual representations. We deconstructed each representation into subcomponents and 
Box 1

Inventory of the 15 Latin American food-based dietary guideline (FBDG) visual representations available online between March and April 2017.

\begin{tabular}{|c|c|c|c|c|c|c|}
\hline Country & $\begin{array}{l}\text { Official } \\
\text { name }\end{array}$ & $\begin{array}{c}\text { Food } \\
\text { diagram } \\
\text { shape }\end{array}$ & $\begin{array}{c}\text { 1st } \\
\text { Edition }\end{array}$ & $\begin{array}{l}\text { Current } \\
\text { edition }\end{array}$ & $\begin{array}{c}\text { Development process and } \\
\text { stakeholders }\end{array}$ & Image description \\
\hline Argentina & $\begin{array}{l}\text { Gráfica de la } \\
\text { Alimentación } \\
\text { Diaria (Graph } \\
\text { of Daily Food) }\end{array}$ & Circle & 2000 & 2015 & $\begin{array}{l}\text { The updating of the dietary guidelines } \\
\text { was coordinated by the Directorate } \\
\text { of Health Promotion and Control of } \\
\text { Noncommunicable Diseases within } \\
\text { the Ministry of Health. The process } \\
\text { was supported by the Ministry of } \\
\text { Social Development and the Ministry } \\
\text { of Agriculture, academia, professional } \\
\text { associations, and other entities. }\end{array}$ & $\begin{array}{l}\text { Three concentric circles: the inner circle } \\
\text { represents the water consumption; the } \\
\text { middle ring presents recommendations } \\
\text { for the consumption of six food groups; } \\
\text { the outermost ring emphasizes on } \\
\text { physical activity and reduction in salt } \\
\text { intake. }\end{array}$ \\
\hline Bolivia & $\begin{array}{c}\text { Arco de la } \\
\text { Alimentación } \\
\text { (Arc of the } \\
\text { Feeding) }\end{array}$ & $\begin{array}{l}\text { Arc/ } \\
\text { rainbow }\end{array}$ & 2013 & 2013 & $\begin{array}{l}\text { The dietary guidelines were developed } \\
\text { by a technical committee coordinated } \\
\text { by the Ministry of Health and Sports } \\
\text { with representatives of the National } \\
\text { Association of Nutritionists and } \\
\text { academia. The messages were } \\
\text { validated with the participation } \\
\text { of nutritionists, medical doctors, } \\
\text { nurses, professors, housewives, and } \\
\text { agronomists. }\end{array}$ & $\begin{array}{l}\text { The Bolivian FBDG was inspired by a } \\
\text { rainbow and expressed seven food groups } \\
\text { in different sizes and color. Each slice of } \\
\text { the semicircle expresses the number of } \\
\text { portions that should be consumed from } \\
\text { each of the seven food groups. At the top } \\
\text { of the rainbow the message "consume } \\
\text { daily food from all groups in your meals" is } \\
\text { written. The center of the image features } \\
\text { a pot of gold. }\end{array}$ \\
\hline Chile & $\begin{array}{l}\text { Gráfica de } \\
\text { la Guías de } \\
\text { Alimentación } \\
\text { Sana (Graph } \\
\text { of Healthy } \\
\text { Eating } \\
\text { Guidelines) }\end{array}$ & Circle & 1997 & 2015 & $\begin{array}{l}\text { The updating of the dietary guidelines } \\
\text { was coordinated by the Department } \\
\text { of Nutrition and Food of the Ministry } \\
\text { of Health, in collaboration with the } \\
\text { INTA of the University of Chile. The } \\
\text { process was attended by experts and } \\
\text { social communicators, who included } \\
\text { representatives from FAO, JUNAEB, } \\
\text { JUNJI, health services, and universities. }\end{array}$ & $\begin{array}{l}\text { Two concentric circles, with an external } \\
\text { semicircle. The inner circle represents } \\
\text { water consumption by a water jug with six } \\
\text { glasses of water. The middle ring presents } \\
\text { recommendations of consumption of six } \\
\text { food groups, each labeled with different } \\
\text { colored headings. To the right of the } \\
\text { image, a green semi-circle with images } \\
\text { of people engaged in various physical } \\
\text { activities is observed. A horizontal black } \\
\text { bar with pictures of foods to avoid is } \\
\text { below these images. }\end{array}$ \\
\hline Colombia & $\begin{array}{c}\text { Plato } \\
\text { Saludable } \\
\text { de la Familia } \\
\text { Colombiana } \\
\text { (The } \\
\text { Colombian } \\
\text { Family's } \\
\text { Healthy Dish) }\end{array}$ & Plate & 2000 & 2014 & $\begin{array}{l}\text { The updating of the dietary } \\
\text { guidelines was coordinated by } \\
\text { the Colombian Institute of Family } \\
\text { Wellness. This process was attended } \\
\text { by an interdisciplinary technical } \\
\text { committee with representatives from } \\
\text { the Ministry of Health, Ministry of } \\
\text { Agriculture and Rural Development, } \\
\text { Ministry of Environment, Ministry of } \\
\text { Culture, National Institute of Health, } \\
\text { universities, and National Association } \\
\text { of Nutritionists, among others. }\end{array}$ & $\begin{array}{l}\text { A plate with foods divided into differently- } \\
\text { sized slices is on a diagonal "placemat" } \\
\text { with a fork and spoon on either side. A } \\
\text { glass of water is in the upper right corner, } \\
\text { while four images depict different physical } \\
\text { activities beneath the plate image. }\end{array}$ \\
\hline Costa Rica & $\begin{array}{l}\text { Guía } \\
\text { Alimentarias } \\
\text { para Costa } \\
\text { Rica (The } \\
\text { Healthy } \\
\text { Eating Circle) }\end{array}$ & Circle & 1997 & 2010 & $\begin{array}{l}\text { The updating of the dietary guidelines } \\
\text { was coordinated by the Ministry of } \\
\text { Health and was supported by various } \\
\text { government ministries, the National } \\
\text { Nutrition Institute, universities, and the } \\
\text { INCAP. }\end{array}$ & $\begin{array}{l}\text { A circle divided into four radial slices } \\
\text { indicating food groups. Each slice has } \\
\text { different sizes, colors, and names. To the } \\
\text { left, images of various forms of physical } \\
\text { activity are shown, while a pitcher and a } \\
\text { glass of water are depicted on the right. }\end{array}$ \\
\hline
\end{tabular}

(continues) 
Box 1 (continued)

\begin{tabular}{|c|c|c|c|c|c|c|}
\hline Country & $\begin{array}{l}\text { Official } \\
\text { name }\end{array}$ & $\begin{array}{c}\text { Food } \\
\text { diagram } \\
\text { shape }\end{array}$ & $\begin{array}{c}\text { 1st } \\
\text { Edition }\end{array}$ & $\begin{array}{l}\text { Current } \\
\text { edition }\end{array}$ & $\begin{array}{l}\text { Development process and } \\
\text { stakeholders }\end{array}$ & Image description \\
\hline Cuba & $\begin{array}{l}\text { La Mesa de la } \\
\text { Alimentación } \\
\text { Saludable } \\
\text { (The Healthy } \\
\text { Eating Table) }\end{array}$ & Table & 2000 & 2009 & \begin{tabular}{|} 
The updating of the dietary guidelines \\
was coordinated by the Institute of \\
Nutrition and Food Hygiene of Cuba, \\
with participation of government \\
ministries (health, agriculture, \\
education, domestic trade) as well as of \\
individuals from universities, organized \\
civil society, specialized medical \\
institutes, restaurants, and the food \\
industry.
\end{tabular} & $\begin{array}{l}\text { Seven plates of various sizes are arranged } \\
\text { hierarchically. Text accompanies each } \\
\text { plate, which represents a particular food } \\
\text { group. It does not mention the practice of } \\
\text { physical activity, consumption of water or } \\
\text { sugars, fats and salt. We emphasize that } \\
\text { Cuba has the highest literacy rate in Latin } \\
\text { America ( } 99.8 \% \text { ), and its population is able } \\
\text { to understand the messages written in the } \\
\text { visual representations of its FBDG. }\end{array}$ \\
\hline $\begin{array}{l}\text { Dominican } \\
\text { Republic }\end{array}$ & $\begin{array}{l}\text { Pilón de la } \\
\text { Alimentación } \\
\text { y Nutrición } \\
\text { (The Mortar } \\
\text { of Food and } \\
\text { Nutrition) }\end{array}$ & Mortar & 2009 & 2009 & $\begin{array}{c}\text { The guidelines were developed in a } \\
\text { process led by the Office of the First } \\
\text { Lady and the Ministry of Public Health, } \\
\text { in collaboration with other ministries, } \\
\text { universities, consumer groups, the FAO, } \\
\text { the INCAP, and the PAHO. }\end{array}$ & $\begin{array}{l}\text { This image features a pestle with small } \\
\text { icons depicting specific foods. The pestle } \\
\text { itself is inside a mortar; five bands are } \\
\text { on the exterior of the mortar, each } \\
\text { representing different food groups. The } \\
\text { pestle and mortar is on a cutting board. } \\
\text { On the board itself, images of a toddler } \\
\text { at various stages of dietary intake (from } \\
\text { breastfeeding to solid foods) are observed. }\end{array}$ \\
\hline Guatemala & $\begin{array}{c}\text { La Olla } \\
\text { Familiar (The } \\
\text { Family Pot) }\end{array}$ & Clay Pot & 1996 & 2012 & $\begin{array}{l}\text { The updating of the dietary guidelines } \\
\text { was coordinated by the Ministry of } \\
\text { Public Health and Social Assistance, } \\
\text { with participation of representatives } \\
\text { from ministries, the Department } \\
\text { of Food and Nutritional Security, } \\
\text { universities, consumer groups, the } \\
\text { national nutrition association, non- } \\
\text { governmental organizations, and the } \\
\text { food industry. The country received } \\
\text { support and technical assistance from } \\
\text { the FAO, the INCAP, the PAHO, UNICEF } \\
\text { and the USAID. }\end{array}$ & $\begin{array}{c}\text { A Guatemalan clay cooking pot, } \\
\text { divided into seven vertical sectors, } \\
\text { which represent food groups arranged } \\
\text { hierarchically. The top of the cooking pot } \\
\text { contains an image of people practicing } \\
\text { physical activity and a picture of a glass of } \\
\text { water. }\end{array}$ \\
\hline Honduras & $\begin{array}{l}\text { Guías } \\
\text { Alimentarias } \\
\quad \text { para } \\
\text { Honduras: } \\
\text { La Olla } \\
\text { (Honduras' } \\
\text { Food Guide: } \\
\text { a Pot) }\end{array}$ & Pot & 2011 & 2013 & $\begin{array}{l}\text { The updating of the dietary guidelines } \\
\text { was coordinated by the National Food } \\
\text { Security Program of the Ministry of } \\
\text { Health, with the participation of the } \\
\text { PAHO, the Institute of Nutrition for } \\
\text { INCAP, FAO, the National Pedagogical } \\
\text { University Francisco Morazán, the } \\
\text { World Vision Honduras, and the } \\
\text { Secretary of the Presidency, through } \\
\text { the Technical Unit of Food and } \\
\text { Nutritional Security. }\end{array}$ & $\begin{array}{l}\text { A pot divided into four different food } \\
\text { groups of varying sizes and colors and } \\
\text { arranged hierarchically. The top of the pot } \\
\text { has a spoon with specific ingredients (oil, } \\
\text { butter, salt, and sugar). On the right, there } \\
\text { is a picture of a glass of water and the } \\
\text { squad of people doing exercises. At the } \\
\text { top of the center, the message "advice for } \\
\text { a healthy diet" is written. }\end{array}$ \\
\hline
\end{tabular}

(continues) 
Box 1 (continued)

\begin{tabular}{|c|c|c|c|c|c|c|}
\hline Country & $\begin{array}{l}\text { Official } \\
\text { name }\end{array}$ & $\begin{array}{c}\text { Food } \\
\text { diagram } \\
\text { shape }\end{array}$ & $\begin{array}{c}\text { 1st } \\
\text { Edition }\end{array}$ & $\begin{array}{l}\text { Current } \\
\text { edition }\end{array}$ & $\begin{array}{c}\text { Development process and } \\
\text { stakeholders }\end{array}$ & Image description \\
\hline Mexico & $\begin{array}{l}\text { El Plato del } \\
\text { Bien Comer } \\
\text { (The plate of } \\
\text { Good Eating) }\end{array}$ & Plate & Unknown & 2015 * & $\begin{array}{l}\text { The development of the dietary } \\
\text { guidelines was coordinated by an } \\
\text { expert committee with representatives } \\
\text { from the National Institute of Public } \\
\text { Health, the Ministry of Health, the } \\
\text { National Institute of Nutrition and } \\
\text { Medical Sciences Salvador Zubirán, } \\
\text { Universidad Iberoamericana, the } \\
\text { Ogali Nutrition Consultants, and the } \\
\text { National Academy of Medicine. In } \\
\text { addition, several representatives from } \\
\text { civil society, as well as national and } \\
\text { international experts, reviewed an } \\
\text { early version of the guidelines and } \\
\text { participated in an international meeting } \\
\text { to provide their input. }\end{array}$ & $\begin{array}{l}\text { The plate includes images of different } \\
\text { food groups and cutlery. The plate is } \\
\text { divided in three parts with different sizes } \\
\text { and colors, each one representing a food } \\
\text { group. The plate has a band around it } \\
\text { with a different color for each group: } \\
\text { green for vegetables and fruits, yellow } \\
\text { for cereals, and red for legumes and } \\
\text { animal products. A message advises to } \\
\text { "combine" between the red and yellow } \\
\text { food groups. }\end{array}$ \\
\hline Panama & $\begin{array}{c}\text { El Plato de la } \\
\text { Alimentación } \\
\text { (The Plate } \\
\text { of Healthy } \\
\text { Eating) }\end{array}$ & Plate & 1997 & 2013 & $\begin{array}{l}\text { The updating of the dietary guidelines } \\
\text { was led by the Dietary Guidelines } \\
\text { National Committee, which was } \\
\text { composed of members from the } \\
\text { Ministry of Health, Ministry of } \\
\text { Education, academics, nutrition } \\
\text { associations, and consumer groups. } \\
\text { The INCAP and the PAHO provided } \\
\text { technical assistance. }\end{array}$ & $\begin{array}{l}\text { A circle with radial slices of various sizes } \\
\text { and colors, each indicates one of the five } \\
\text { food groups. The circle are inserted in a } \\
\text { plate, as assumed by the inclusion of a } \\
\text { fork, a knife, and a glass of water, all of } \\
\text { which are on a placemat. }\end{array}$ \\
\hline Paraguay & $\begin{array}{l}\text { El Pote } \\
\text { Nutricional } \\
\text { Paraguayo } \\
\quad \text { (The } \\
\text { Paraguayan } \\
\text { Nutitional } \\
\text { Pot) }\end{array}$ & Pot & 1999 & 2015 & $\begin{array}{l}\text { The updating of the dietary guidelines } \\
\text { was led by the National Dietary } \\
\text { Guidelines Technical Committee, under } \\
\text { the coordination and supervision of } \\
\text { the National Institute for Food and } \\
\text { Nutrition and the Ministry of Public } \\
\text { Health and Social Welfare. The FAO } \\
\text { and the PAHO provided technical } \\
\text { assistance. }\end{array}$ & $\begin{array}{c}\text { The pot is divided into seven parts, } \\
\text { each one representing food groups in } \\
\text { different sizes and colors. In addition, } \\
\text { a color code, similar to the traffic light, } \\
\text { is used to indicate which foods should } \\
\text { be eaten in larger or smaller quantities. } \\
\text { Two additional recommendations are } \\
\text { provided outside the pot, as illustrations: } \\
\text { drinking water and doing physical } \\
\text { activity. }\end{array}$ \\
\hline Uruguay & $\begin{array}{c}\text { El Set } \\
\text { Saludable } \\
\text { (The Healthy } \\
\text { Set) }\end{array}$ & Circle & 2005 & 2015 & $\begin{array}{l}\text { The dietary guidelines were updated by } \\
\text { the Nutrition Programmatic Area under } \\
\text { the Ministry of Public Health, with the } \\
\text { support of an intersectorial group with } \\
\text { representatives from different public } \\
\text { sector institutions, academia and civil } \\
\text { society organizations. }\end{array}$ & $\begin{array}{l}\text { The circle includes seven food groups, } \\
\text { represented by various foods placed on } \\
\text { differently-sized and colored slices. A } \\
\text { pitcher of water is at the center. Another } \\
\text { circle containing images suggesting } \\
\text { movement/daily activities, as well as } \\
\text { how individuals should enjoy their } \\
\text { food, surrounds these foods. Additional } \\
\text { directives are included below the main } \\
\text { food circle, as words "+ actividad física" } \\
\text { and "- sal y azúcar". }\end{array}$ \\
\hline
\end{tabular}

(continues) 
Box 1 (continued)

\begin{tabular}{|c|c|c|c|c|c|c|}
\hline Country & $\begin{array}{l}\text { Official } \\
\text { name }\end{array}$ & $\begin{array}{c}\text { Food } \\
\text { diagram } \\
\text { shape }\end{array}$ & $\begin{array}{c}\text { 1st } \\
\text { Edition }\end{array}$ & $\begin{array}{l}\text { Current } \\
\text { edition }\end{array}$ & $\begin{array}{c}\text { Development process and } \\
\text { stakeholders }\end{array}$ & Image description \\
\hline Venezuela & \begin{tabular}{|c|} 
El Trompo \\
(The Food \\
Spinning Top)
\end{tabular} & $\begin{array}{l}\text { Spinning } \\
\text { top }\end{array}$ & 1991 & 1991 & \begin{tabular}{|} 
The development of the dietary \\
guidelines was led by the National \\
Nutrition Institute and the Cavendes \\
Foundation, in collaboration with the \\
Central University of Venezuela and the \\
Simon Bolivar University of Venezuela.
\end{tabular} & $\begin{array}{l}\text { The spinning top is divided into five } \\
\text { sections hierarchically arranged, each one } \\
\text { indicating one food group. The "string" of } \\
\text { the tromp is a stylized river upon which } \\
\text { a woman, a man and a child are playing } \\
\text { soccer. }\end{array}$ \\
\hline Venezuela & \begin{tabular}{|c|} 
El Trompo \\
(The food \\
Spinning Top)
\end{tabular} & \begin{tabular}{|c|} 
Spinning \\
top \\
indigenous
\end{tabular} & 1991 & 1991 & \begin{tabular}{|} 
The development of the dietary \\
guidelines was led by the National \\
Nutrition Institute and the Cavendes \\
Foundation, in collaboration with the \\
Central University of Venezuela and the \\
Simon Bolivar University of Venezuela
\end{tabular} & $\begin{array}{l}\text { The spinning top is divided into five } \\
\text { sections hierarchically arranged, each one } \\
\text { indicating one food group. The "string" of } \\
\text { the tromp is a stylized river upon which } \\
\text { an indigenous person is fishing and an } \\
\text { individual is canoeing. The background of } \\
\text { this particular FBDG includes indigenous } \\
\text { artwork/symbolism. }\end{array}$ \\
\hline
\end{tabular}

FAO: Food and Agriculture Organization of the United Nations; INCAP: Institute of Nutrition of Central America and Panama; INTA: Institute of Nutrition and Food Technology; JUNAEB: Junta Nacional de Auxilio Escolar y Becas; JUNJI: Sistema Nacional de Jardines Infantiles; PAHO: Pan American Health Organization; UNICEF: United Nations Children's Fund; USAID: United States Agency for International Development.

* The visual representations were not revised with the current 2015 Guidelines.

further interpreted their symbolic meanings, repeating the above steps as necessary to elicit better understandings of our image inventory on national and regional scales (Box 2). This iterative process also helped us to understand the links between the FBDG textbooks and specific images that were chosen to represent recommendations. For example, we analyzed the foods comprising each food group. An individual image of a chicken is a representation of a chicken. However, grouping chickens alongside images of pigs and cows could mean collectively a suggestion to consume foods from a "meat" or "protein" category, while their inclusion alongside capybaras and insects may indicate traditional food sources of specific cultural groups 18 .

\section{Results and discussions}

\section{Development and stakeholders}

Latin American countries published their first FBDGs between 1991 and 2011; many of these textbooks were updated between 2009 and 2015 ( $\mathrm{n}=10$ ). All countries used the model proposed by INCAP to develop, review and update their respective FBDGs. The model promotes the involvement of national panels of scientists, policymakers and stakeholders to compile the best scientific, cultural and political evidence for health-promotion and disease-prevention behaviors available at the time of FBDG development 6,8. The Ministries of Health of each country had a central role in these processes, being responsible for leading or coordinating the national multisectoral work committees. These committees were composed of stakeholders from the academic sector, as well as of professional associations from the health area, civil society, agricultural sector, and food industry. Organizations such as FAO, INCAP, and PAHO have provided technical support to countries in developing their official dietary guidelines (Box 1). Most countries' Ministries of Health endorse food guidelines, with coauthorship by universities, nutritionist or medical associations, and/or other ministries (education, agriculture, labor and development). 
Box 2

Summary of elements that compose the 15 Latin American food-based dietary guideline (FBDG) visual representations available online between March and April 2017.

\begin{tabular}{|c|c|c|c|c|c|c|c|c|c|}
\hline \multirow[t]{2}{*}{ Country } & \multirow{2}{*}{$\begin{array}{l}\text { Pictorial } \\
\text { diagram }\end{array}$} & \multicolumn{3}{|c|}{ Food classification system } & \multicolumn{5}{|c|}{ Sociocultural practices } \\
\hline & & & Food groups & $\begin{array}{c}\text { Salt, sugar, fat, or } \\
\text { other specific food/ } \\
\text { Nutrients/Ingredients }\end{array}$ & $\begin{array}{l}\text { Physical } \\
\text { activity }\end{array}$ & $\begin{array}{c}\text { Water } \\
\text { consumption }\end{array}$ & $\begin{array}{l}\text { Culinary } \\
\text { practices }\end{array}$ & Commensality & $\begin{array}{c}\text { System of } \\
\text { cultural symbols }\end{array}$ \\
\hline Argentina & Circle & 6 & $\begin{array}{l}\text { (1) Fruits and } \\
\text { vegetables; } \\
\text { (2) legumes, } \\
\text { cereals, } \\
\text { potatoes, } \\
\text { bread, and } \\
\text { pastas; (3) } \\
\text { milk, yogurt, } \\
\text { and cheese; (4) } \\
\text { meat (including } \\
\text { fish) and eggs; } \\
\text { (5) oils, dried } \\
\text { fruits, and } \\
\text { grains; and } \\
\text { (6) optional: } \\
\text { sweets and } \\
\text { fats. }\end{array}$ & $\begin{array}{c}\text { Yes - reduction in salt } \\
\text { intake at the bottom } \\
\text { of the image; sweets } \\
\text { and fats categorized } \\
\text { separately, but as part } \\
\text { of total diet rather than } \\
\text { completely separate } \\
\text { (just as salt). }\end{array}$ & $\begin{array}{l}\text { Yes - } \\
\text { placement } \\
\text { at the top of } \\
\text { the image: } \\
\text { + physical } \\
\text { activity. }\end{array}$ & $\begin{array}{c}\text { Yes - water } \\
\text { faucet with } \\
\text { running water } \\
\text { in the center } \\
\text { of the FBDG. }\end{array}$ & No. & No. & $\begin{array}{c}\text { Text on } \\
\text { packaging in } \\
\text { Spanish (e.g., } \\
\text { arroz, avena, } \\
\text { leche, queso); } \\
\text { some of the } \\
\text { ingredients may } \\
\text { be regional or } \\
\text { traditional to } \\
\text { Argentina. }\end{array}$ \\
\hline Bolivia & $\begin{array}{l}\text { Arc/ } \\
\text { rainbow }\end{array}$ & 7 & $\begin{array}{c}\text { (1) Cereals, } \\
\text { legumes, } \\
\text { tubers, and } \\
\text { derivatives; (2) } \\
\text { vegetables; (3) } \\
\text { fruits; (4) milk } \\
\text { and derivatives; } \\
\text { (5) meats, } \\
\text { derivatives, } \\
\text { eggs and mixed } \\
\text { vegetables; (6) } \\
\text { fats and oils; } \\
\text { and (7) sugars } \\
\text { and jams. }\end{array}$ & $\begin{array}{c}\text { Yes - moderate } \\
\text { consumption of fat, oils, } \\
\text { sugar, and jams. The } \\
\text { salt shaker is placed on } \\
\text { the right-hand side of } \\
\text { the arc, alongside the } \\
\text { groups that are advised } \\
\text { to be consumed in } \\
\text { moderate proportions; } \\
\text { as such, smaller } \\
\text { portion of salt intake is } \\
\text { suggested. }\end{array}$ & No. & $\begin{array}{c}\text { Yes - the glass } \\
\text { of water is } \\
\text { placed on the } \\
\text { left-hand side } \\
\text { of the arc, } \\
\text { alongside the } \\
\text { grain group, } \\
\text { which has } \\
\text { the largest } \\
\text { number of } \\
\text { portions } \\
\text { suggested; } \\
\text { as such, } \\
\text { larger portion } \\
\text { of water } \\
\text { consumption } \\
\text { is suggested. }\end{array}$ & No. & No. & $\begin{array}{c}\text { Pot of native } \\
\text { dish; images } \\
\text { appear to convey } \\
\text { ingredients } \\
\text { native or } \\
\text { traditional to } \\
\text { Bolivia. }\end{array}$ \\
\hline
\end{tabular}

(continues) 
Box 2 (continued)

\begin{tabular}{|c|c|c|c|c|c|c|c|c|c|}
\hline \multirow[t]{2}{*}{ Country } & \multirow{2}{*}{$\begin{array}{l}\text { Pictorial } \\
\text { diagram }\end{array}$} & \multicolumn{3}{|c|}{ Food classification system } & \multicolumn{5}{|c|}{ Sociocultural practices } \\
\hline & & & Food groups & $\begin{array}{c}\text { Salt, sugar, fat, or } \\
\text { other specific food/ } \\
\text { Nutrients/Ingredients }\end{array}$ & $\begin{array}{l}\text { Physical } \\
\text { activity }\end{array}$ & $\begin{array}{c}\text { Water } \\
\text { consumption }\end{array}$ & $\begin{array}{l}\text { Culinary } \\
\text { practices }\end{array}$ & Commensality & $\begin{array}{l}\text { System of } \\
\text { cultural } \\
\text { symbols }\end{array}$ \\
\hline Chile & Circle & 6 & $\begin{array}{c}\text { (1) Fruits; (2) } \\
\text { dairy products; } \\
\text { (3) meats, } \\
\text { leguminous } \\
\text { and eggs; (4) } \\
\text { whole grain; } \\
\text { (5) oils; and (6) } \\
\text { vegetables. }\end{array}$ & $\begin{array}{c}\text { Yes - a black strip } \\
\text { that indicates to avoid } \\
\text { sugar, salt, candies, soft } \\
\text { drinks, fast foods (hot } \\
\text { dog and French fries), } \\
\text { and ultra-processed } \\
\text { foods (soft drink, ice } \\
\text { cream, and candies). }\end{array}$ & $\begin{array}{c}\text { Yes - "daily } \\
\text { physical } \\
\text { activity" is } \\
\text { written in a } \\
\text { green strip } \\
\text { around the } \\
\text { circle, and } \\
\text { the image of } \\
\text { people walking, } \\
\text { running, } \\
\text { playing soccer, } \\
\text { cycling, and } \\
\text { skateboarding, } \\
\text { alone or } \\
\text { accompanied, } \\
\text { and displaying } \\
\text { adults, children } \\
\text { and elderlies. }\end{array}$ & $\begin{array}{c}\text { Yes - the } \\
\text { center of the } \\
\text { circle contains } \\
\text { a jar of water } \\
\text { with } 6 \text { cups } \\
\text { full of water. } \\
\text { Indicating the } \\
\text { ideal amount } \\
\text { of daily water } \\
\text { consumption. }\end{array}$ & No. & No. & $\begin{array}{c}\text { Grain and } \\
\text { legume images } \\
\text { appear to be } \\
\text { most clearly } \\
\text { depicting } \\
\text { endemic foods. }\end{array}$ \\
\hline Colombia & Plate & 6 & $\begin{array}{c}\text { (1) Cereals, } \\
\text { root vegetables } \\
\text { and products; } \\
\text { (2) fruits and } \\
\text { vegetables; } 3 . \\
\text { milk and dairy; } \\
\text { (4) meat, eggs, } \\
\text { pulses and } \\
\text { nuts; (5) fats; } \\
\text { and (6) sugars. }\end{array}$ & 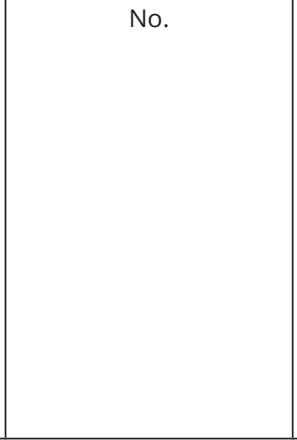 & $\begin{array}{l}\text { Yes - the image } \\
\text { of children } \\
\text { and adults } \\
\text { practicing } \\
\text { physical } \\
\text { activities such } \\
\text { as dancing, } \\
\text { cycling, playing } \\
\text { soccer, and } \\
\text { walking. }\end{array}$ & $\begin{array}{c}\text { Yes - there is } \\
\text { a glass full of } \\
\text { water on the } \\
\text { plate. }\end{array}$ & No. & No. & $\begin{array}{l}\text { It represents } \\
\text { utensils for food } \\
\text { consumption } \\
\text { such as dish, } \\
\text { fork, spoon, and } \\
\text { glass, besides } \\
\text { expressing } \\
\text { native or } \\
\text { traditional foods } \\
\text { especially in the } \\
\text { grain category. }\end{array}$ \\
\hline $\begin{array}{l}\text { Costa } \\
\text { Rica }\end{array}$ & Circle & 4 & $\begin{array}{c}\text { (1) Cereals, } \\
\text { legumes } \\
\text { and starchy } \\
\text { vegetables; } \\
\text { (2) vegetables } \\
\text { and fruits; (3) } \\
\text { animal-source } \\
\text { foods; (4) fats } \\
\text { and sugars. }\end{array}$ & No. & $\begin{array}{l}\text { Yes - children } \\
\text { and adults } \\
\text { practicing } \\
\text { a physical } \\
\text { activity such } \\
\text { as walking, } \\
\text { running, and } \\
\text { cycling. }\end{array}$ & $\begin{array}{c}\text { Yes - next to } \\
\text { the circle is a } \\
\text { jar and a glass } \\
\text { of water. }\end{array}$ & No. & $\begin{array}{c}\text { Yes - it is } \\
\text { recommended } \\
\text { to make the } \\
\text { basic mealtimes } \\
\text { accompanied } \\
\text { by family, } \\
\text { friends, or } \\
\text { companion so } \\
\text { that it is a space } \\
\text { for socialization } \\
\text { and rest. }\end{array}$ & $\begin{array}{l}\text { The cereal } \\
\text { group, which } \\
\text { takes up most } \\
\text { of the circle, } \\
\text { appears to } \\
\text { include native } \\
\text { or traditional } \\
\text { ingredients. }\end{array}$ \\
\hline
\end{tabular}

(continues) 
Box 2 (continued)

\begin{tabular}{|c|c|c|c|c|c|c|c|c|c|}
\hline \multirow[t]{2}{*}{ Country } & \multirow{2}{*}{$\begin{array}{l}\text { Pictorial } \\
\text { diagram }\end{array}$} & \multicolumn{3}{|c|}{ Food classification system } & \multicolumn{5}{|c|}{ Sociocultural practices } \\
\hline & & & Food groups & \begin{tabular}{|c|}
$\begin{array}{c}\text { Salt, sugar, fat, or } \\
\text { other specific food/ } \\
\text { Nutrients/Ingredients }\end{array}$ \\
\end{tabular} & $\begin{array}{l}\text { Physical } \\
\text { activity }\end{array}$ & \begin{tabular}{|c|} 
Water \\
consumption
\end{tabular} & $\begin{array}{l}\text { Culinary } \\
\text { practices }\end{array}$ & Commensality & $\begin{array}{l}\text { System of } \\
\text { cultural } \\
\text { symbols }\end{array}$ \\
\hline Cuba & Table & 7 & \begin{tabular}{|c|} 
(1) Cereals and \\
derivatives; \\
(2) vegetables; \\
(3) fruits; (4) \\
meats, fish, \\
poultry, eggs \\
and beans; (5) \\
milk, yogurt \\
and cheeses; \\
(6) fats; and (7) \\
sugar.
\end{tabular} & $\begin{array}{c}\text { Yes - the image } \\
\text { promotes the } \\
\text { consumption of } \\
\text { vegetable oils, reducing } \\
\text { the consumption } \\
\text { of sugar and salt. It } \\
\text { suggests to remove the } \\
\text { salt shaker from the } \\
\text { table. }\end{array}$ & No. & No. & No. & No. & $\begin{array}{l}\text { Plate designs; } \\
\text { foods/ } \\
\text { ingredients } \\
\text { native or } \\
\text { traditional to } \\
\text { Cuba. }\end{array}$ \\
\hline $\begin{array}{l}\text { Dominican } \\
\text { Republic }\end{array}$ & Mortar & 8 & \begin{tabular}{|c|} 
(1) Human or \\
breast milk; \\
(2) normal \\
or fortified \\
cereals; (3) \\
beans; (4) \\
food sources \\
of energy \\
and complex \\
carbohydrates; \\
(5) fruits and \\
vegetables; (6) \\
eggs, milks and \\
dairy products; \\
(7) fish, poultry, \\
meats and \\
viscera; and (8) \\
fat, sugar and \\
iodized salt.
\end{tabular} & $\begin{array}{c}\text { Yes - the fats, sugars, } \\
\text { and iodized salt are } \\
\text { located on the smallest } \\
\text { part of the pestle, } \\
\text { which indicates that } \\
\text { they should be eaten } \\
\text { in very small quantities } \\
\text { and/or limited to } \\
\text { the minimal amount } \\
\text { needed for cooking. } \\
\end{array}$ & $\begin{array}{c}\text { Yes - } 4 \text { images } \\
\text { with a yellow } \\
\text { tint behind the } \\
\text { mortar and } \\
\text { pestle, which } \\
\text { depict different } \\
\text { physical } \\
\text { activities: } \\
\text { swimming, } \\
\text { dancing, } \\
\text { baseball, and } \\
\text { soccer. The } \\
\text { people in these } \\
\text { images are of } \\
\text { different ages. }\end{array}$ & \begin{tabular}{|c|} 
Yes - a small \\
icon at the \\
base of the \\
mortar shows \\
a bottle of \\
water being \\
poured into \\
a glass. (the \\
instructional \\
text is difficult \\
to read). \\
\end{tabular} & No. & No. & $\begin{array}{c}\text { The image of } \\
\text { dancers in the } \\
\text { background, } \\
\text { as well as } \\
\text { some of the } \\
\text { foods depicted } \\
\text { on the mortar. }\end{array}$ \\
\hline Guatemala & Clay Pot & 7 & \begin{tabular}{|c|} 
(1) Cereals, \\
grains, and \\
tubers; (2) \\
herbs and \\
vegetables; \\
(3) fruits; (4) \\
meats; (5) milk \\
and derivatives; \\
(6) sugars; (7) \\
and fat.
\end{tabular} & $\begin{array}{l}\text { Yes - moderation } \\
\text { in sugar and fat } \\
\text { consumption. }\end{array}$ & $\begin{array}{l}\text { Yes - images } \\
\text { of man and } \\
\text { woman cycling } \\
\text { and running } \\
\text { are displayed } \\
\text { on the pot. }\end{array}$ & $\begin{array}{c}\text { Yes - one } \\
\text { glass of water } \\
\text { is displayed } \\
\text { on the top of } \\
\text { the pot. }\end{array}$ & No. & No. & $\begin{array}{l}\text { The clay } \\
\text { cooking pot } \\
\text { itself. In } \\
\text { addition to } \\
\text { some of the } \\
\text { foods native } \\
\text { or traditional } \\
\text { to Guatemala, } \\
\text { a packaged } \\
\text { good includes } \\
\text { Spanish } \\
\text { language. }\end{array}$ \\
\hline
\end{tabular}

(continues) 
Box 2 (continued)

\begin{tabular}{|c|c|c|c|c|c|c|c|c|c|}
\hline \multirow[t]{2}{*}{ Country } & \multirow{2}{*}{$\begin{array}{l}\text { Pictorial } \\
\text { diagram }\end{array}$} & \multicolumn{3}{|c|}{ Food classification system } & \multicolumn{5}{|c|}{ Sociocultural practices } \\
\hline & & & Food groups & $\begin{array}{c}\text { Salt, sugar, fat, or } \\
\text { other specific food/ } \\
\text { Nutrients/Ingredients }\end{array}$ & $\begin{array}{l}\text { Physical } \\
\text { activity }\end{array}$ & \begin{tabular}{|c|} 
Water \\
consumption
\end{tabular} & $\begin{array}{l}\text { Culinary } \\
\text { practices }\end{array}$ & Commensality & $\begin{array}{l}\text { System of } \\
\text { cultural } \\
\text { symbols }\end{array}$ \\
\hline Honduras & Pot & 5 & \begin{tabular}{|c|} 
(1) Cereals, \\
grains, and \\
tubers; (2) fruits, \\
greens, and \\
vegetables; (3) \\
eggs, milk, and \\
derivatives; (4) \\
meat; (5) and \\
sugar and fat.
\end{tabular} & $\begin{array}{l}\text { Yes - Less quantity of } \\
\text { sugar, fat, and salt. }\end{array}$ & \begin{tabular}{|c|} 
Yes - An icon \\
of man and \\
women jogging \\
and the phrase \\
"do exercises".
\end{tabular} & $\begin{array}{c}\text { Yes - one } \\
\text { glass of water } \\
\text { is displayed } \\
\text { on the top of } \\
\text { the pot. }\end{array}$ & No. & No. & $\begin{array}{l}\text { The food } \\
\text { guide is a pot. } \\
\text { In addition to } \\
\text { typical dishes } \\
\text { and utensils } \\
\text { used for } \\
\text { consumption } \\
\text { of meals. }\end{array}$ \\
\hline Mexico & Plate & 5 & $\begin{array}{l}\text { (1) Vegetables; } \\
\text { (2) fruits; (3) } \\
\text { legumes; (4) } \\
\text { animal-based } \\
\text { food; and (5) } \\
\text { cereals. }\end{array}$ & $\begin{array}{l}\text { No - the assumption } \\
\text { would be to avoid } \\
\text { consuming such foods } \\
\text { altogether. }\end{array}$ & No. & No. & No. & No. & $\begin{array}{c}\text { Typical dishes } \\
\text { and utensils } \\
\text { used for } \\
\text { consumption } \\
\text { of meals, } \\
\text { such as: plate, } \\
\text { fork, knife, } \\
\text { and spoon. } \\
\text { Many of the } \\
\text { pictured foods } \\
\text { clearly appear } \\
\text { to be native or } \\
\text { traditional to } \\
\text { Mexico. }\end{array}$ \\
\hline Panama & Plate & 8 & \begin{tabular}{|c|} 
(1) Starches, \\
grains, and \\
cereals; (2) fruits \\
and vegetables; \\
(3) meats; (4) \\
dairy products; \\
and (5) oils, fats, \\
and sugars.
\end{tabular} & $\begin{array}{l}\text { Yes - Fatty oils and } \\
\text { sugars are specifically } \\
\text { included as foods } \\
\text { to consume, though } \\
\text { notably in relatively } \\
\text { lower proportion than } \\
\text { the other food groups. }\end{array}$ & \begin{tabular}{|c|} 
Yes - the \\
phrase "eat \\
healthy, move, \\
and live better".
\end{tabular} & $\begin{array}{c}\text { Yes - a glass } \\
\text { of water and } \\
\text { the message } \\
\text { "eight times a } \\
\text { day". }\end{array}$ & $\begin{array}{c}\text { Use natural } \\
\text { seasonings } \\
\text { such as } \\
\text { garlic, onion, } \\
\text { coriander, } \\
\text { parsley, } \\
\text { spring } \\
\text { onions, } \\
\text { oregano, and } \\
\text { pepper. Use } \\
\text { little oil and } \\
\text { cooking fats. } \\
\text { Avoid fried } \\
\text { foods. }\end{array}$ & No. & $\begin{array}{c}\text { Kitchen } \\
\text { utensils such } \\
\text { as: plate, } \\
\text { fork, knife, } \\
\text { and glass. } \\
\text { Also, native } \\
\text { or traditional } \\
\text { food to } \\
\text { Panama. }\end{array}$ \\
\hline Paraguay & Pot & 7 & \begin{tabular}{|c|} 
(1) Cereals, \\
tubers, and \\
derivatives; \\
(2) fruits; (3) \\
vegetables; \\
(4) milk and \\
derivatives;(5) \\
meats, legumes, \\
and egg; (6) \\
sugars and \\
honey; and (7) \\
oils and fats.
\end{tabular} & $\begin{array}{l}\text { Yes - sugars, honey, } \\
\text { oils, and fats are } \\
\text { recommended in small } \\
\text { quantities. }\end{array}$ & $\begin{array}{c}\text { Yes - photos of } \\
\text { children playing } \\
\text { soccer. }\end{array}$ & \begin{tabular}{|c|} 
Yes - an \\
image of \\
a woman \\
drinking a \\
glass of water.
\end{tabular} & No. & No. & $\begin{array}{l}\text { The pot. Many } \\
\text { of the foods } \\
\text { on the FBDG } \\
\text { image appear } \\
\text { to be native } \\
\text { or traditional } \\
\text { to Paraguay. } \\
\text { All of the } \\
\text { packaged } \\
\text { foods clearly } \\
\text { include text in } \\
\text { Spanish. }\end{array}$ \\
\hline
\end{tabular}

(continues) 
Box 2 (continued)

\begin{tabular}{|c|c|c|c|c|c|c|c|c|c|}
\hline \multirow[t]{2}{*}{ Country } & \multirow{2}{*}{$\begin{array}{l}\text { Pictorial } \\
\text { diagram }\end{array}$} & \multicolumn{3}{|c|}{ Food classification system } & \multicolumn{5}{|c|}{ Sociocultural practices } \\
\hline & & & Food groups & \begin{tabular}{|c|} 
Salt, sugar, fat, or \\
other specific food/ \\
Nutrients/Ingredients
\end{tabular} & $\begin{array}{l}\text { Physical } \\
\text { activity }\end{array}$ & $\begin{array}{c}\text { Water } \\
\text { consumption }\end{array}$ & $\begin{array}{l}\text { Culinary } \\
\text { practices }\end{array}$ & Commensality & $\begin{array}{l}\text { System of } \\
\text { cultural } \\
\text { symbols }\end{array}$ \\
\hline Uruguay & Circle & 7 & $\begin{array}{l}\text { (1) Vegetables } \\
\text { and legumes; } \\
\text { (2) breads, } \\
\text { flours, pasta, } \\
\text { rice, and } \\
\text { potatoes; (3) } \\
\text { fruits; (4) milks } \\
\text { and cheeses; } \\
\text { (5) meat, fish, } \\
\text { and eggs; (6) } \\
\text { seeds and oils; } \\
\text { and (7) sugar } \\
\text { and sweets. }\end{array}$ & $\begin{array}{c}\text { Yes - avoid products } \\
\text { such as fries; nuggets, } \\
\text { pancho, hamburgers, } \\
\text { and cold meats; soda, } \\
\text { artificial juices, and } \\
\text { flavored waters; snacks; } \\
\text { alfajores and crackers; } \\
\text { ice cream and sweets; } \\
\text { instant broths and } \\
\text { soups, and dressing in } \\
\text { the day to day. }\end{array}$ & $\begin{array}{l}\text { Yes. A "move" } \\
\text { message and } \\
\text { illustrations } \\
\text { of people } \\
\text { practicing } \\
\text { physical } \\
\text { activity in the } \\
\text { circle. Outside } \\
\text { the circle } \\
\text { the message } \\
\text { "+ physical } \\
\text { activity" is } \\
\text { observed. }\end{array}$ & $\begin{array}{l}\text { Yes - water is } \\
\text { on the center } \\
\text { of the circle. }\end{array}$ & $\begin{array}{c}\text { Cooking } \\
\text { traditional } \\
\text { foods is } \\
\text { good for you: } \\
\text { discover the } \\
\text { joy of cooking } \\
\text { and share } \\
\text { this activity. } \\
\text { Choose oil } \\
\text { for cooking } \\
\text { instead of } \\
\text { other fats. } \\
\text { Avoid buying } \\
\text { products } \\
\text { with some } \\
\text { excessive } \\
\text { quantities of } \\
\text { fat, especially } \\
\text { the ones with } \\
\text { trans-fat. } \\
\text { Reduce the } \\
\text { salt and sugar } \\
\text { added when } \\
\text { cooking: } \\
\text { small } \\
\text { quantities are } \\
\text { enough to } \\
\text { give flavors. }\end{array}$ & $\begin{array}{c}\text { Enjoy your } \\
\text { food: eat slowly } \\
\text { and, when } \\
\text { possible, eat } \\
\text { accompanied. } \\
\text { The message } \\
\text { "eat healthy and } \\
\text { enjoy the food" } \\
\text { outside the } \\
\text { circle and, next } \\
\text { to it, images } \\
\text { with two people } \\
\text { making food } \\
\text { purchases, a } \\
\text { family eating } \\
\text { at the table; } \\
\text { two people } \\
\text { cooking; a } \\
\text { family making a } \\
\text { meal at a table } \\
\text { with two arrows } \\
\text { pointing to a } \\
\text { television, and } \\
\text { a cell phone } \\
\text { with the a stripe } \\
\text { above it. } \\
\end{array}$ & $\begin{array}{c}\text { While the } \\
\text { foods pictured } \\
\text { on the image } \\
\text { do not } \\
\text { necessarily } \\
\text { look native or } \\
\text { traditional to } \\
\text { Uruguay, some } \\
\text { of the foods } \\
\text { specifically } \\
\text { suggested } \\
\text { to avoid } \\
\text { (panchos, } \\
\text { fiambres, } \\
\text { alfajores) } \\
\text { are culturally } \\
\text { indicative. }\end{array}$ \\
\hline Venezuela & $\begin{array}{l}\text { Spinning } \\
\text { top }\end{array}$ & 5 & $\begin{array}{l}\text { (1) Cereals, } \\
\text { tubers, grains, } \\
\text { and bananas; } \\
\text { (2) fruits and } \\
\text { vegetables; (3) } \\
\text { meat, eggs, } \\
\text { milk, and dairy } \\
\text { products; (4) } \\
\text { vegetable fats } \\
\text { and oils; and (5) } \\
\text { sugar, honey, } \\
\text { and sugar } \\
\text { cane. }\end{array}$ & $\begin{array}{l}\text { Yes - it recommends } \\
\text { reducing salt, sugar, } \\
\text { and fat. }\end{array}$ & \begin{tabular}{|c|} 
Yes - in both \\
spinning \\
tops, physical \\
activity is what \\
propels the \\
water rope. The \\
guide for the \\
nonindigenous \\
population \\
presents \\
images of \\
a children \\
playing ball, a \\
man practicing \\
cycling, and \\
a woman \\
running.
\end{tabular} & $\begin{array}{l}\text { Yes. The } \\
\text { water is the } \\
\text { rope that is } \\
\text { spinning the } \\
\text { top. }\end{array}$ & No. & No. & $\begin{array}{l}\text { The spinning } \\
\text { top itself and } \\
\text { regional or } \\
\text { traditional } \\
\text { foods. }\end{array}$ \\
\hline
\end{tabular}

(continues) 
Box 2 (continued)

\begin{tabular}{|c|c|c|c|c|c|c|c|c|}
\hline \multirow[t]{2}{*}{ Country } & \multirow{2}{*}{$\begin{array}{l}\text { Pictorial } \\
\text { diagram }\end{array}$} & \multicolumn{2}{|c|}{ Food classification system } & \multicolumn{5}{|c|}{ Sociocultural practices } \\
\hline & & Food groups & $\begin{array}{c}\text { Salt, sugar, fat, or } \\
\text { other specific food/ } \\
\text { Nutrients/Ingredients }\end{array}$ & $\begin{array}{l}\text { Physical } \\
\text { activity }\end{array}$ & $\begin{array}{c}\text { Water } \\
\text { consumption }\end{array}$ & $\begin{array}{l}\text { Culinary } \\
\text { practices }\end{array}$ & Commensality & $\begin{array}{l}\text { System of } \\
\text { cultural } \\
\text { symbols }\end{array}$ \\
\hline Venezuela & $\begin{array}{c}\text { Indigenous } \\
\text { spinning } \\
\text { top }\end{array}$ & \begin{tabular}{|c|c|} 
(1) Cereals, \\
tubers, grains, \\
and bananas; \\
(2) fruits and \\
vegetables; (3) \\
meat, eggs, \\
milk, and dairy \\
products; (4) \\
vegetable fats \\
and oils; and (5) \\
sugar, honey, \\
and sugar cane.
\end{tabular} & $\begin{array}{l}\text { Yes - It recommends } \\
\text { reducing salt, sugar, } \\
\text { and fat. }\end{array}$ & $\begin{array}{l}\text { Yes - the } \\
\text { images show } \\
\text { indigenous } \\
\text { people with } \\
\text { typical clothes } \\
\text { practicing } \\
\text { canoeing and } \\
\text { fishing with } \\
\text { harpoon. }\end{array}$ & $\begin{array}{l}\text { Yes. The } \\
\text { water is the } \\
\text { rope that is } \\
\text { spinning the } \\
\text { top. }\end{array}$ & No. & No. & $\begin{array}{l}\text { Foods such as } \\
\text { game meats } \\
\text { (alligator, } \\
\text { capybara, } \\
\text { and others) } \\
\text { and insects, } \\
\text { in addition } \\
\text { to symbols } \\
\text { from different } \\
\text { Venezuela's } \\
\text { tribes. }\end{array}$ \\
\hline
\end{tabular}

\section{Shape of visual representations}

In our study, we recognized four general shape patterns: circular, plate, "traditional cooking utensils" 11 and "unique" 9 (Box 3).

Circular FBDG graphics (represented by the images from Argentina 19, Chile 20, Costa Rica 21, and Uruguay 22) express proportions of food groups for a daily or weekly diet 23 , using a geometric concept associated with a "continuous process" (without beginning or end) 24. The use of concentric circles in Argentina, Chile, and Uruguay highlights healthy lifestyles as more than just the consumption of balanced and healthy food; it also includes to varying degrees cooking, commensality, physical activity, and water consumption.

Plate visual representations (Colombia 25, Mexico 26, and Panama 27) differ from circular ones in that they express food group proportions relative to daily meals. The meal-based approach is further emphasized alongside cutlery, water glass and a placemat, all of which may suggest a normative way to present food based on hegemonically widespread cultural instruments in urban Western societies.

"Traditional cooking utensils" 11 - clay pot, pot, and mortar - as expressed in Dominican Republic 28, Guatemala 29, Honduras 30, and Paraguay 31 representations are illustrative frameworks that harken traditional foodways and cooking from scratch. This approach contrasts with representations of circles and plates, because it relies on a relatively hierarchical (bottom-up) reading of food groups, while the others feature a relatively horizontal (i.e., non-hierarchical) orientation 24,32 . Furthermore, the traditional utensil approach emphasizes national culture not only in terms of food choices but also regarding physical activity (as we explore below).

"Unique" 9 visual representations that do not fit into one of the other groups vary in their overall structures, as well as their approaches to symbolically articulate proportionality (Cuba's differentlysized plates 33), variety (Bolivia's rainbow 34), and cultural relevance (Venezuela's trompo 35,36). The recommended relative contributions of different food groups to the overall diet are a common denominator in these images 3 .

\section{Dietary norms of the visual representations}

Dietary norms are a set of prescriptions based on scientific-nutritional knowledge, which change according to scientific progress over time ${ }^{37}$. These norms emerged in our analysis, given FBDGs' foci on variety, proportionality and moderation, as expressed in the concepts of food groups and food portions. Similar depictions of such recommendations are arguably unsurprising since Latin American 
Box 3

General patterns of visual representation shapes of the Latin American Food-Based Dietary Guidelines available online, between March and April 2017.

\begin{tabular}{|l|c|c|}
\hline General shape patterns & Food diagram shapes & Countries \\
\hline Circle & Circle & Argentina (2015), Chile (2015), Costa Rica (2010), \\
and Uruguay (2016)
\end{tabular}

countries have long shared similar sources when developing their FBDGs (e.g., adoption of the global Plan of Action for Nutrition and/or guidance from the INCAP model). These features are particularly salient when considering depictions of food classification systems and food standards considered healthy. While we would argue that these norms are inherently sociocultural, we make the distinction that they most immediately refer to dietary needs.

\section{- Food classification system}

A food group is a system of food organization according to similarity in nutritional properties or biological classifications 38. Among the visual representations reviewed, we found symbolized nutrients of the food groups, which were not explicitly illustrated. The number of food groups varies from four to eight (Box 2), whereby basic organization appears to be rooted in macronutrients, biological classification (e.g., meats and fruits) or inclusion in regular meals. According to the simplest classifications, such as Costa Rica's, food groups are organized by nutritional and biological characteristics: (1) fruits and vegetables; (2) cereals, leguminous, and starchy vegetables; (3) animal foods; and (4) sugars and fats.

Classification complexity increases due to greater subdivisions based on food processing level, industrial addition of micronutrients (food fortification), breastfeeding valorization, and inclusion of "empty calories" (e.g., sugars). Consider the Dominican Republic's visual representation: (1) human milk; (2) normal or fortified cereals; (3) legumes; (4) starchy foods; (5) fruits and vegetables; (6) eggs, milk, and derivatives; (7) fish, poultries, meats and bowels; (8) fats, sugars, and iodized salt. We interpret this FBDG's representation of breastfeeding as a normative mode of introducing food in early infancy, which coincides with recommendations by WHO and United Nations Children's Fund (UNICEF) ${ }^{39}$. The fact that this is included in an FBDG for people 2+ years old further suggests healthy eating starts in early childhood.

Food groups are closely associated with the FBDG concept of "variety", which expresses proper proportions and food consumption quantities. Consequently, it is linked to the concept of food portions; this, in turn, corresponds to the average amount of food that should be consumed by a healthy individual, aiming at promoting adequate consumption of energy and nutrients 40 . Here, we suggest using food groups and food portion sizes relates symbolically to daily recommendations for energy and nutrient intake 41. In circular, plate or arc diagrams, food groups are indicated by labels and/or images (stylized illustrations or photo-realistic images of specific foods), as well as the relative size of their portion of the diagram, with associated colors indicating relative serving amounts. By contrast, the verticality of traditional utensil representations indicates the frequency or suggested portions of consumption, whereas a "traffic light" color code system informs greater or moderate consumption of a food group, as in the cases of Mexico and Paraguay. All these fundamental informational elements determine the permission or restriction of a food group. 


\section{- Food standards considered healthy}

In addition to the food classification system, recent visual representations (such as that of Uruguay) emphasize levels of food processing, suggesting that healthy diets are based on in natura foods and that people should avoid consuming ultra-processed foods 42,43 . While all visual representations illustrate several fresh foods, some also include the accompaniment of text that explicitly states the avoidance of specific foods (e.g., Chile; Cuba), or a minus (-) sign next to or near foods to avoid (e.g., Argentina; Uruguay). The Uruguayan visual representation also includes images and a list, written in Spanish, of foods that should be avoided altogether, many of them being ultra-processed (e.g., chicken nuggets and instant soups).

Food-processing level has become a public health concern given scientific evidence suggesting a positive association between consumption of ultra-processed foods and obesity and/or noncommunicable diseases (NCDs) in several countries 44,45. FBDGs began to emphasize food-processing levels from the Brazilian experience with the second edition of the Dietary Guidelines for the Brazilian Population, which uses the NOVA food classification 46,47. This classification is based on the nature, extent and purpose of food processing before food acquisition, preparation and consumption 42,43 . Although no Latin American FBDG visual representation uses the NOVA classification, they do emphasize food-processing levels in other ways.

Among all the FBDGs reviewed, cereals comprise the most recommended food group to consume $27,29,30,31,33,34,35,36$, followed by fruits and vegetables 19,20,21,22,26, dairy products 19,20,21,22,25,26,27, $28,29,30,31,33,34,35,36$ and, finally, meat and eggs $19,20,21,22,25,26,27,28,29,30,31,33,34,35,36$. Some of these groups have caveats, as articulated in FBDG textbooks, though they are not necessarily conveyed on the FBDG images themselves. Cereals are encouraged in their whole form to increase consumption of complex carbohydrates and dietary fiber, as suggested by the inclusion of various grains on Bolivia's food arc. As exemplified by Guatemala and Honduras, milks, cheeses and yogurts should be consumed in their skim form to reduce saturated fat intake. As for meats, there is an incentive to consume lean cuts and avoid fat ones, as well as to avoid consuming ultra-processed forms (e.g., ham, sausages and others, as illustrated on the Chile's FBDG image).

Overall, it appears clear that consumers are advised not to consume sugary drinks, alcoholic beverages, sweets, artificial spices, and other ultra-processed foods. The concern with these foods derives from the intake of specific nutritional components such as simple sugars, saturated and trans fats, sodium and food additives (e.g., flavorings, colors, and preservatives) 19,20,27,28,29,30,31,33,34,35,36. Moreover, the consumption of ultra-processed foods and fast foods contributes to reducting the consumption of foods or culinary preparations based on in natura, native, and/or traditional foods 48 .

\section{Sociocultural norms of visual representations}

Sociocultural norms are a set of conventions relating to the structural composition of food intake during and outside meals - as well as to the conditions and contexts of food consumption 37 . These norms emerged in our analysis through our identification of cultural symbols, i.e., the manifestation of a system of representations of a given culture, through which human beings communicate, perpetuate and develop their knowledge and attitudes towards life 49 . Such symbols include typified traditional foods, national dishes, culinary tools, and images of people, which, in turn, act as markers of identity and social belonging and are key to implementation and subsequent response to issues of NCDs and overall health 50. In addition to evoking dietary recommendations, each country's FBDG further contextualizes local food, cooking, customs, economy, and food production capacity 1,40.

Here, we suggest depictions of sociocultural norms are intended to counteract contemporary eating modes in Latin America, such as the devaluation of home-cooked meals, the mealtime flexibility and the individualization of eating rituals and timing 45,48,51. Consequently, this strategy would aim to restore and promote normative and social control systems, as evidenced by recommendations regarding traditional foods, cooking practices, commensality, water consumption, and physical activity. 


\section{- Traditional foods}

The repetition of certain foods became apparent when we compared the Latin American visual representations. Indeed, it seems quite logical that similar environments would produce similar ingredients for regional consumption ${ }^{52}$. Concurrently, we were able to identify features that were arguably more unique or not repeated. We can more likely identify these images as "culturally important" (meaningful enough to the country that it is included on the visual representation); "native" (regionally or locally situated); and/or "traditional" (knowledge regarding specific foods and foodways shared between generations 53 ).

All the visual representations reviewed include some combination of this latter categorization. This is shown by including typical culinary preparations (e.g., fried corn tortillas, burritos, and tacos) as in the Chilean, Mexican, Paraguayan, and Uruguayan representations. We also observe depictions of regional and local foods and preparations that subscribe a "nationality" of eating practices, in the case of Bolivia (via the consumption of quinoa, amaranth, and chia), or mark ethnic-cultural differences, such as in the Venezuelan case, which values indigenous symbols and encourages the consumption of insects, wild animals and other local food sources.

We suggest including these culturally meaningful foods conveys the biological, nutritional and cultural importance of their consumption. Moreover, this is read as a strategy to connect and make visual representations relevant and acceptable to consumers 1,50. Through their adoption, one promotes not only local consumption, but also biodiversity and regional foodways 54 . However, determining distinctive dietary guidelines for indigenous populations as separate from the national FBDG may lead to their ongoing marginalization by promoting norms of dominant groups that separate national ("us") and indigenous ("them") foods 18.

\section{- Cooking practices}

In addition to consuming local traditional foods, Latin American visual representations appear to suggest cooking from scratch with fresh/raw ingredients is important. This is especially evident through the illustration of culinary utensils, such as the Dominican Republic's mortar and pestle. This symbol of native cuisine is found in many Dominican kitchens and is an autochthonous item, meaning that the origin and learning of its use is transmitted from generation to generation.

Latin American visual representations generally acknowledge salt, sugar and fat as culinary ingredients, though in small quantities and in steering consumers toward non-frying cooking practices (e.g., boiling, simmering). However, only the visual representations of Panama and Uruguay address this theme of culinary practice per se. Panama's illustrates natural seasonings and small quantities of oils and fats for cooking, whereas Uruguay's promotes domestic cooking and traditional preparations, stating that using only small amounts of salt, sugar and fat is enough to produce flavors.

We infer cooking from scratch recommendations as strategies to increase the consumption of fruits and vegetables reduces the consumption of fast and/or ultra-processed foods and the risk of overweight and obesity 55. In addition, the appreciation of culinary practice recognizes national/ regional preparations as processes related to the identities and senses of citizens' social and cultural belonging, as well as the autonomy, pleasure and well-being of individuals and groups 56,57.

\section{- Commensality}

In a strict sense, commensality means "eating with other people" 58 . Only Uruguay's visual representation conveys this notion. Its graphic also recognizes commensality as more than just consuming food with family members, but also buying and preparing food with them. It also normalizes places dedicated to meals and encourages meal consumption with little to no distraction.

Commensality is not a key feature across all the images we reviewed. However, we recognize related elements, which are expressed through recommendations to eat regularly (all visual representations), with attention (e.g., Uruguay) and with appropriate utensils in specific environments (e.g., plate images). Promoting commensality valorizes eating as a social activity, contrasting it with solodining models propelled by the ultra-processed food industry. Family environment is valued, which 
can greatly influence members' eating habits, as it provides them with food for consumption, support for eating practices and development of food skills 58 .

Having said this, we observe an emphasis on a single model of family organization across many of the visual representations - a typified heteronormative nuclear family - which could reflect a social pattern of representation, interpretation and communication that results in a non-recognition and disregard for other forms of familial grouping. Examples of this reading include potential families silhouetted in Colombia and Costa Rica's visual representations.

\section{- Water consumption}

Latin American visual representations generally emphasize the consumption of filtered, boiled or sanitary (i.e., safe) water; a minimum of six to eight glasses a day is suggested to maintain perfect balance so that the body can fulfill its functions, as depicted in some images (e.g., Chile). Consuming soft drinks, ultra-processed juices, flavored water, alcoholic beverages and other sugary beverages is considered harmful to a population's overall health, as suggested by their depiction in visual representations (e.g., Uruguay).

Water consumption is represented as several glasses, drinking from a bottle, pouring from a pitcher or collecting from a faucet. This diversity demonstrates the multiplicity and variety of ways to consume water according to customs and the drinking water quality and sanitation infrastructures in each country. To this end, we proposed multiple interpretations: countries that encourage their population to drink from a faucet generally have better water quality or trust in the government and other sources to provide safe drinking water (e.g., Argentina 59); whereas those that picture bottled water (e.g., Bolivia and the Dominican Republic) may have relatively lower access to safe drinking water 45 , or governments may be orienting FBDGs to social groups that can afford bottled water.

Here, we emphasize the importance of water, as it is essential not only for regular human consumption, but also for food production and preparation. Contaminated water is the vehicle for the transmission of any pathogens and pollutants from the environment and food chain at large, with ensuing implications for food safety 45 . Thus, including water in FBDG images and emphasizing messages about its quality are strategies that place the "right to potable water" in the public health and social development agenda.

\section{- Physical activity}

The visual representations reviewed communicate physical activity recommendations through images of individuals engaged in such activities or through written recommendations (Boxes 1 and 2). Recommendations are possibly related to: the energy balance of consuming energy through food and expending it through physical activity, the direct benefits of such practices to health 1,60, and more sedentary leisure activities (e.g., watching television).

Visual representations include specific textual messages, or images of children, adults and elderly people practicing physical activities. Across all shapes, physical activity is expressed in all traditional cooking utensil visual representations, as in the case of the Dominican Republic's inclusion of dancing merengue or running. More cultural representations are used by Venezuela's graphics, with a visual distinction for physical activity between nonindigenous (soccer, cycling, or running) and indigenous peoples (canoeing and fishing with a harpoon).

\section{Limitations}

Our study has some limitations. Visual anthropological approaches are often best paired with verbal cues (e.g., interviewing FBDG creators or citizens) 15,16, which were lacking here. In addition, our lack of knowledge regarding Nicaragua's dietary guidelines may skew our interpretation of dietary behaviors throughout the region. However, our interpretations of all FBDG images available were further supported by FBDG textbooks and based on an understanding that visual representations influence public perceptions about healthy eating and lifestyles. 


\section{Conclusion}

The visual representations reviewed express dietary and sociocultural norms influencing the construction of healthy eating and lifestyles, including local foods and foodways. Our review of Latin American FBDG visual representations reveals similarities in the ways that countries attempt to promote healthy eating and lifestyles using concurrent biological, social and cultural imagery. The presentation of certain foods conveys biological aspects with the logic that food provides the energy and nutrients necessary to maintain an active and healthy body. FBDG images reflect sociological arguments that promote a normative system and social control over quality, quantity and manners of eating foods.

At the same time, the choice of which symbolic elements to include in a visual representation reflects desires to connect with consumers and express the country's cultural uniqueness (compared with other FBDG images of the region) concerning the traditional foods and foodways of the people belonging to its population. This is particularly evident when considering the fruit and vegetable recommendations, which we further argue are related to production practices in each Latin American country 45 , and the promotion of traditional culinary preparations and mealtime staples such as cereals, roots, and tubers.

Alongside reinforcing regional and local identity, food and eating can play roles related to the family ties, cultural identity and comfort of eaters 45,57. In the case of Latin American visual representations, such images convey normative behaviors that rely on typified family structures and urban eating habits. Some images also suggest a "proper" way to consume meals, using pictures of plates, cutlery, glasses, and people/families eating at the table. Moreover, directives to enjoy food and social relations that occur between diners at mealtime (e.g., do not watch television or use the cell phone during meals) are just as important as the food and dietary guidelines themselves.

Finally, visual representations tend to depict "national" food patterns or idealized meals that may obscure regional food patterns or diversity within the same country. As such, we suggest that FBDG visual representations could be neglecting certain forms of knowledge and practices about food, health, and nutrition, as well as sociocultural conceptions of the body and beauty of other ethnic and social groups. The inclusion of specific cultural symbols can thus help (or hurt) the successful implementation of FBDGs through cultural appeal and, by extension, a sense of relevant dietary guidance 50,61.

\section{Contributors}

M. S. S. Oliveira, M. A. Arceño, P. M. Sato and F. B. Scagliusi designed the study; M. S. S. Oliveira and M. A. Arceño designed the study methodology, performed data colection, analysis, interpretation, and drafted the study with contributions from the other authors. All the authors read and contributed to the final approval of the manuscript.

\section{Additional informations}

ORCID: Mayara Sanay da Silva Oliveira (00000002-3243-2575); Mark Anthony Arceño (00000002-9046-1374); Priscila de Morais Sato (00000001-9850-6859); Fernanda Baeza Scagliusi (00000001-7590-4563).

\section{Acknowledgments}

The authors are grateful for the financial support from Coordenação de Aperfeiçoamento de Pessoal de Nível Superior (Capes, grant numbers 1718057); Fundação de Amparo à Pesquisa do Estado de São Paulo (FAPESP, grant number 2017/05651-0; grant number 2017/17424-9), and Conselho Nacional de Desenvolvimento Científico e Tecnológico (CNPq, grant number 311357/2015-6). We also would like to thank the members of the Research Group on Food and Culture of the University of São Paulo (GPAC/USP). 


\section{References}

1. Food and Agriculture Organization of the United Nations. A manual from the Englishspeaking Caribbean: developing food-based dietary guidelines. Rome: Food and Agriculture Organization of the United Nations; 2007.

2. División de Nutrición, Organización de las Naciones Unidas para la Alimentación y la Agricultura. El estado de guías alimentarias basadas en alimentos en América Latina y el Caribe: 21 años después de la Conferencia Internacional sobre Nutrición. Roma: Organización de las Naciones Unidas para la Alimentación y la Agricultura; 2014.

3. Gonzalez C, Garnett T, editors. Plates, pyramid and planets - developments in national healthy and sustainable dietary guidelines: a state of play assessment. s.l.: Food and Agriculture Organization of the United Nations/ Food Climate Research Network/University of Oxford; 2016.

4. Schneeman BO. Evolution of dietary guidelines. J Am Diet Assoc 2003; 103 Suppl 2:5-9.

5. Barbosa RMS, Colares LGT, Soares EA. Desenvolvimento de guias alimentares em diversos países. Rev Nutr 2008; 21:455-67.

6. Morón C, Calderón T. La elaboración de guías alimentarias basadas en alimentos en países de América Latina. Food, Nutrition and Agriculture 1999; 24:19-28.

7. Keller I, Lang T. Food-based dietary guidelines and implementation: lessons from four countries - Chile, Germany, New Zealand and South Africa. Public Health Nutr 2008; 11:867-74.

8. Molina V. Guías alimentarias en América Latina: informe de la consulta técnica regional de las guías alimentarias. An Venez Nutr 2008; 21:31-41.

9. Painter J, Rah JH, Lee YK. Comparison of international food guide pictorial representations. J Am Diet Assoc 2002; 102:483-9.

10. Altamirano Martínez MB, Cordero Muñoz AY, Macedo Ojeda G, Márquez Sandoval YF, Vizmanos B. A review of graphical representations used in the dietary guidelines of selected countries in the Americas, Europe and Asia. Nutr Hosp 2015; 32:986-96.

11. Montagnese C, Santarpia L, Iavarone F, Strangio F, Caldara AR, Silvestri E, et al. North and South American countries food-based dietary guidelines: a comparison. Nutrition 2017; 42:51-63.

12. Food and Agroculture Organization of the United Nations. Food-based dietary guidelines; 2017. http://www.fao.org/nutrition/ nutrition-education/food-dietary-guidelines/ en/ (accessed on 01/Mar/2017).

13. Ministério da Saúde. Resolução no 466, de 12 de dezembro de 2012. Diário Oficial da União 2013; 13 jun.

14. Hockings P, Tomaselli KG, Ruby J, MacDougall $\mathrm{D}$, Williams D, Piette A. Where is the theory in visual anthropology? Visual Anthropology 2014; 27:436-56.
15. Collier M. Approaches to analysis in visual anthropology. In: Leeuwen TV, Jewitt C, editors. The handbook of visual analysis. London: Sage; 2001. p. 35-60.

16. Collier J, Collier M. Visual anthropology: photography as a research method. Albuquerque: University of New Mexico Press; 1986.

17. Wiles R, Prosser J, Bagnoli A, Clark A, Daves K, Holland S, et al. Visual ethics: ethical issues in visual research. Southampton: National Centre for Research Methods; 2008.

18. Arceño MA. On consuming and constructing material and symbolic culture: an anthropology of pictorial representations of Food-Based Dietary Guidelines (FBDGS) [Master's Thesis]. Ohio: The Ohio State University; 2016.

19. Ministerio de Salud. Mensajes y gráfica de las guías alimentarias para la población Argentina. Buenos Aires: Ministerio de Salud; 2015.

20. Ministerio de Salud. Guías de alimentación sana. Santiago: Ministerio de Salud; 2014.

21. Comisión Intersectorial de Guías Alimentarias para Costa Rica; Ministerio de Salud. Guías alimentarias para Costa Rica. San José: Comisión Intersectorial de Guias Alimentarias para Costa Rica; 2010.

22. Ministerio de Salud Pública; Organización Panamericana de la Salud. Guía alimentaria para la población uruguaya: para una alimentación saludable, compartida y placentera. Montevideo: Ministerio de Salud Pública; 2016.

23. Oberritter $H$, Schäbethal $K$, von Ruesten A. The DGE Nutrition Circle - presentation and basis of the food-related recommendations from the German Nutrition Society (DGE). Ernaehrungs Umschau International 2013; 60:24-9.

24. Kaufer-Horwitz M, Valdés-Ramos R, Willett WC, Anderson A, Salomons NW. A comparative analysis of the scientific basis and visual appeal of seven dietary guideline graphics. Nutr Res 2005; 25:335-47.

25. Instituto Colombiano de Bienestar Familiar; Organización de las Naciones Unidas para la Alimentación y Agricultura. Guías alimentarias basadas en alimentos para la población colombiana mayor de 2 años. Bogotá: Instituto Colombiano de Bienestar Familiar/Organización de las Naciones Unidas para la Alimentación y Agricultura; 2015.

26. Bonvecchio Arenas A, Fernández-Gaxiola AC, Belausteguigoitia MP, Kaufer-Horwitz M, Pérez Lizaur AB, Rivera Dommarco JAR, editores. Guías alimentarias y de actividad física en contexto de sobrepeso y obesidad en la población mexicana. Ciudad de México: Intersistemas; 2015.

27. Organización Panamericana de la Salud; Ministerio de Salud de la República de Panamá. Guías alimentarias para Panamá. Ciudad de Panamá: Ministerio de Salud de la República de Panamá; 2013. 
28. Subsecretaría de Nutrición. Guías alimentarias basadas en alimentos de la República Dominicana. Santo Domingo: Subsecretaría de Nutrición; 2009.

29. Ministerio de Salud Pública y Asistencia Social. Guía alimentaria para Guatemala: recomendaciones para una alimentación saludable. Ciudad de Guatemala: Ministerio de Salud Pública y Asistencia Social; 2012.

30. Secretaria de Estado del Despacho Presidencial. Guías alimentarias para Honduras: consejos para una alimentación sana. Tegucigalpa: Secretaria de Estado del Despacho Presidencial; 2013.

31. Ministerio de Salud Pública y Bienestar Social La olla nutricional paraguaya: guías alimentarias del Paraguay. Asunción: Instituto Nacional de Alimentación y Nutrición; 2015.

32. Truman E. Exploring the visual appeal of food guide graphics: a compositional analysis of dinner plate modles. Br Food J 2018; 120:1682-95.

33. Instituto de Nutrición e Higiene de los Alimentos, Ministerio de Salud Pública. Guías alimentarias para la población cubana mayor de dos años de edad. Ciudad de La Habana: Ministerio de Salud Pública; 2009.

34. Dirección General de Promoción de la Salud, Ministerio de Salud. Bases técnicas de las guías alimentarias para la población boliviana. La Paz: Ministerio de Salud/Editorial Quatro Hnos; 2013.

35. Ministerio del Poder Popular para la Alimentación. El trompo de los alimentos: democratizando la cultura alimentaria y nutricional. Caracas: Ministerio del Poder Popular para la Alimentación; 1991.

36. Ministerio del Poder Popular para la Alimentación. El trompo de los alimentos indígena. Caracas: Ministerio del Poder Popular para la Alimentación; 1991.

37. Poulain JP, Proença RPC. Reflexões metodológicas para o estudo das práticas alimentares. Rev Nutr (Online) 2003; 16:365-86.

38. Brázdová Z, Fiala J, Bauerová J, Hrubá D. Dietary guidelines in the Czech Republic. I.: theoretical background and development. Cent Eur J Public Health 2000; 8:186-90.

39. World Health Organization; United Nations Children's Fund. Global strategy for infant and young child feeding. Geneva: World Health Organization; 2003.

40. Dwyer JT. Dietary standards and guidelines: similarities and differences among countries. In: Erdman JW, Macdonald IA, Zeisel SH, editors. Present knowledge in nutrition. Hoboken: Wiley-Blackwell; 2012. p. 1110-34.

41. Standing Committee on the Scientific Evaluation of Dietary Reference Intakes, Subcommittee on Interpretation and Uses of Dietary Reference Intakes, Institute of Medicine. Dietary reference intakes: applications in dietary planning. Washington DC: National Academy Press; 2003.
42. Monteiro CA, Levy RB, Claro RM, Castro IRR, Cannon G. A new classification of foods based on the extent and purpose of their processing. Cad Saúde Pública 2010; 26:2039-49.

43. Monteiro CA, Cannon G, Moubarac JC, Levy RB, Louzada MLC, Jaime PC. The UN Decade of Nutrition, the NOVA food classification and the trouble with ultra-processing. Public Health Nutr 2018; 21:5-17.

44. Monteiro CA, Moubarac JC, Cannon G, Ng SW, Popkin B. Ultra-processed products are becoming dominant in the global food system. Obes Rev 2013; 14 Suppl 2:21-8.

45. Food and Agriculture Organization of the United Nations; Pan American Health Organization. Panorama of food and nutrition security in Latin America and the Caribbean. Santiago: Food and Agriculture Organization of the United Nations; 2017.

46. Monteiro CA, Cannon G, Moubarac JC, Martins AP, Martins CA, Garzillo J, et al. Dietary guidelines to nourish humanity and the planet in the twenty-first century. a blueprint from Brazil. Public Health Nutr 2015; 18:2311-22.

47. Oliveira MSDS, Amparo-Santos L. Food-based dietary guidelines: a comparative analysis between the Dietary Guidelines for the Brazilian Population 2006 and 2014. Public Health Nutr 2018; 21:210-7.

48. Aguirre P, Díaz Córdova D, Polischer G. Cocinar y comer en Argentina hoy. Buenos Aires: Fundación Sociedad Argentina de Pediatria; 2015.

49. Ortner SB. Theory in Anthropology since the Sixties. Comparative Studies in Society and History 1984; 26:126-66.

50. Neuhauser L, Rothschild R, Rodríguez FM. MyPyramid.gov: assessment of literacy, cultural and linguistic factors in the USDA food pyramid web site. J Nutr Educ Behav 2007; 39:219-25.

51. Moubarac JC, Parra DC, Cannon G, Monteiro CA. Food classification systems based on food processing: significance and implications for policies and actions: a systematic literature review and assessment. Curr Obes Rep 2014; 3:256-72

52. Comisión Económica para América Latina y el Caribe; Organización de las Naciones Unidas para la Agricultura y la Alimentación; Instituto Interamericano de Cooperación para la Agricultura. Perspectivas de la agricultura y del desarrollo rural en las Américas: una mirada hacia América Latina y el Caribe. San José: Instituto Interamericano de Cooperación para la Agricultura; 2014.

53. Shanklin E. Two meanings and used of tradition. J Anthropol Res 1981; 37:71-89.

54. Gil A, Ruiz-Lopez MD, Fernandez-Gonzalez M, Martinez de Victoria E. The FINUT healthy lifestyles guide: beyond the food pyramid. Adv Nutr 2014; 5:358S-67S. 
55. Mills S, White M, Brown H, Wrieden W, Kwasnicka D, Halligan J, et al. Health and social determinants and outcomes of home cooking: a systematic review of observational studies. Appetite 2017; 111:116-34.

56. Food and Agriculture Organization of the United Nations. FAO and traditional knowledge: the linkages with sustainability, food security and climate change impacts. Rome: Food and Agriculture Organization of the United Nations; 2009.

57. Contreras Hernández JC, Gracia Arnáiz M. Alimentación y cultura: perspectivas antropológicas. Barcelona: Ariel; 2005.

58. Fischler C. Commensality, society and culture. Soc Sci Inf 2011; 50:528-48.
59. Olmos Giupponi MB, Paz MC. The implementation of the Human Right to water in Argentina and Colombia. Anuario Mexicano de Derecho Internacional 2015; XV:323-52.

60. World Health Organization. Global strategy on diet, physical activity and health. Geneva: World Health Organization; 2004.

61. The European Food Information Council. The food pyramid: a dietary guideline in Europe; 2009. https://www.eufic.org/en/healthy-liv ing/article/food-based-dietary-guidelines-ineurope (accessed on 01/Jun/2017). 


\section{Resumo}

As representações visuais dos guias alimentares baseados em alimentos (GABAs) expressam normas dietéticas e socioculturais relacionadas aos hábitos alimentares saudáveis. Este artigo investiga as recomendações governamentais de hábitos alimentares saudáveis expressos nas representações visuais de GABAs latino-americanos. Estudamos 15 imagens publicadas entre $1991 \mathrm{e}$ 2017. Realizamos uma análise visual antropológica guiada pela metodologia proposta por James Collier e Malcolm Collier: análise aberta e não estruturada; análise estruturada; e microanálise. Exploramos as recomendações governamentais a partir das formas das representações visuais, sistema de classificação de alimentos, recomendações de estilo de vida e elementos socioculturais. Nossos principais resultados estão relacionados as normas dietéticas e socioculturais usadas para promover hábitos alimentares considerados saudáveis. As normas dietéticas se concentram na variedade, proporcionalidade e moderação expressos nos conceitos de grupos e padrões alimentares saudáveis. As normas socioculturais estão relacionadas ao uso de símbolos culturais como estratégias para promover alimentos tradicionais, prática culinária doméstica, comensalidade, consumo de água e atividade física. Concluímos que as representações visuais dos GABAs contribuem com mensagens que aconselham os individuos a planejar, comprar, preparar e consumir alimentos com a familia; aderir a padrões alimentares considerados saudáveis; realizar refeições com total atenção e sem distração de televisão e celulares; e celebrar comidas ou preparações culinárias tradicionais, locais e/ou nativas.

Dieta Saudável; Política Nutricional; Pesquisa Qualitativa

\section{Resumen}

Las representaciones visuales de las guías alimentarias basadas en alimentos (GABAs) expresan normas dietéticas y socioculturales, relacionadas con hábitos alimentarios saludables. Este artículo investiga las recomendaciones gubernamentales de hábitos alimentarios saludables, expresadas en representaciones visuales de GABAs latinoamericanas. Estudiamos 15 imágenes publicadas entre 1991 y 2017. Realizamos un análisis visual antropológico, guiado por la metodología propuesta por James Collier y Malcolm Collier: análisis abierto y no estructurado; análisis estructurado; y microanálisis. Investigamos las recomendaciones gubernamentales a partir de las formas de representaciones visuales, sistema de clasificación de alimentos, recomendaciones de estilo de vida y elementos socioculturales. Nuestros principales resultados están relacionados con las normas dietéticas y socioculturales usadas para promover hábitos alimentarios considerados saludables. Las normas dietéticas se concentran en: variedad, proporcionalidad y moderación, expresadas en conceptos de grupos y patrones alimentarios saludables. Las normas socioculturales están relacionadas con el uso de símbolos culturales como: estrategias para promover alimentos tradicionales, práctica culinaria doméstica, comensalidad, consumo de agua $y$ actividad física. Concluimos que las representaciones visuales de las GABAs aportan mensajes que aconsejan a los individuos planear, comprar, preparar y consumir alimentos con la familia; adherirse a patrones alimentarios considerados saludables; realizar comidas con total atención y sin distracción de televisión y celulares; y celebrar comidas o platos culinarios tradicionales, locales $y / o$ autóctonos.

Dieta Saludable; Politica Nutricional; Investigación Cualitativa
Submitted on $10 /$ Sep/2018

Final version resubmitted on 26/Mar/2019

Approved on 24/May/2019 